\title{
Characterization of Biosurfactants Enhancing Kerosene Degradation
}

\author{
Dilan Camille Aydin ${ }^{1}$, Bulent Icgen ${ }^{1,2}$ \\ ${ }^{1}$ Department of Biochemistry, Middle East Technical University \\ Ankara, Turkey \\ ${ }^{2}$ Department of Environmental Engineering, Middle East Technical University \\ Ankara, Turkey \\ aydin.dilan@metu.edu.tr; bicgen@ metu.edu.tr
}

\section{Extended Abstract}

Kerosene is a colorless flammable hydrocarbon liquid and it is obtained from the fractional distillation of petroleum [1]. It has numerous applications as fuel for jet engines, heating oil, solvent and insecticide [2]. Because of growing needs of kerosene production and extensive usage may end up with surface water contamination. Due to its high toxicity to biota, kerosene contamination requires remedial action to reduce environmental damage [3]. Biodegradation is an effective and eco-friendly method performed by hydrocarbon degrading bacteria.

Some of hydrocarbon degrading bacteria have the ability to produce extracellular compounds called biosurfactants. Based on their diverse chemical structures, biosurfactants are classified as glycolipids, lipopeptides, phospholipids, fatty acids, neutral lipids, and polysaccharide-protein complexes [4]. Biosurfactants can reduce surface tension and emulsify hydrocarbons by enhancing the bioavailability. They also have advantages over chemical surfactants by having low toxicity, being biodegradable [5] and efficient even at extreme temperature or $\mathrm{pH}$ conditions [6]. Therefore, characterization of biosurfactants produced by hydrocarbon degraders is of great interest especially in environmental applications [4].

This study aimed at determining biosurfactants produced by kerosene degraders. Therefore, previously determined 19 kerosene degraders were primarily screened for their biosurfactant productivity against kerosene. In order to characterize the type of biosurfactant; Phenol- $\mathrm{H}_{2} \mathrm{SO}_{4}$, Biuret, Phosphate and CTAB/Methylene Blue Agar Plate tests were performed. All the isolates showed positive responses to CTAB/Methylene Blue Agar Plate test, confirming the production rhamnolipid biosurfactants [7]. These results were also justified with Fourier Transform Infrared (FTIR) Spectroscopy.

\section{Acknowlegment}

The authors would like to thank Bilkent University National Nanotechnology Research Center (UNAM) for their assistance in FTIR analyses. This study is financially supported by Middle East Technical University Research Fund with the Project number BAP-03-11-2017-001.

\section{References}

[1] M. K. Gouda, H. O. Sanaa, H. M. N. Eldin, A.Z. Chekroud, "Bioremediation of kerosene II: a case study in contaminated clay (Laboratory and field: scale microcosms)," World J Microbiol Biotechnol, 24, pp. 1451-1460, 2008.

[2] C. N. Obinna, F.V. Olutubo, "Biodegradation of Kerosene by Soil Bacterial Species from Contaminated Site," Covenant Journal of Physical and Life Sciences (CJPL), vol. 2, no. 1, 2014.

[3] C. W. Greer, N. Fortin, R. Roy, "Indigenous sediment microbial activity in response to nutrient enrichment and plant growth following a controlled oil spill on a fresh water wetland," Bioremed J, vol. 7, pp. 69-80, 2003.

[4] B. Anandaraj, P. Thivakaran, "Isolation and production of biosurfactant producing organism from oil spilled soil," Biosci Tech, vol 1, no. 3, pp. 120-126, 2010.

[5] B. S. Saharan, R. K. Sahu, D. Sharma, "A Review on Biosurfactants: Fermentation, Current Developments and production," Genetic Engineering and Biotechnology Journal, vol. 2011, 2011. 
[6] E. J. Gudiña, J. A. Teixeira, L. R. Rodrigues, "Biosurfactant-Producing Lactobacilli: Screening, Production," Applied and Environmental Soil Science, vol. 2011, pp. 9, 2011.

[7] C. Rizzo, L. Michaud, B. Hormann, B. Gerce, C. Syldatk, R. Hausmann, E.D. Domenico, A. L. Giudice, "Bacteria associated with sabellids (Polychaeta: Annelida) as a novel source of surface active compounds," Mar. Pollut. Bull., 70, pp. 125-133, 2013. 